\title{
PENGOLAHAN SAMPAH ORGANIK RUMAH TANGGA MENJADI PUPUK BOKASHI SERTA PEMANFAATANNYA BAGI TANAMAN REMPAH DAN PENINGKATAN PENDAPATAN DI KELURAHAN PENFUI
}

\author{
Maria Rosdiana Deno Ratu*, Arnoldus Keban*, Johanes G. Sogen* \\ *Fakultas Peternakan, Universitas Nusa Cendana \\ e-mail: mariadenoratu@staf.undana.ac.id
}

\begin{abstract}
Each household, include community of RT 004/RW 002 Penfui village, Kupang, produced rubbish everyday, both organic and anorganic. The trash, then, were collected at the yard, burnt, or thrown making dirty. Therefore, it was needed to be processed in a Community Joint Program called PKM. The PKM objectives were: 1) to increase the knowledge and skill of the housewives in processing organic trash into fertilizer called bokashi; 2) to apply the bokashi on herbs or selling it to gain an income, and 3) to increase the spices production for daily needs or to sell it. Method were extension, training, demonstration, and mentoring. The result showed that $100 \%$ of the group members were participate actively, so their knowledge, skill, and motivation in producing and selling bokashi and herbs increased, and the livelihood become clean. In conclusion, the PKM: 1) increased the knowledge, skill, and motivation of the members program in processing bokashi to keep the livelihood clean; 2) supported the using of bokashi on herbs or selling it to gain an income; and 3) increased the herbs production.
\end{abstract}

Key-words: clean, organic fertilizer, PKM, spices, yard .

\section{PENDAHULUAN}

\section{Latar Belakang}

Setiap rumahtangga memproduksi sampah setiap hari, baik sampah organik maupun anorganik. Demikian pula halnya warga RT 004/RW 002 Kelurahan Penfui Kota Kupang. 
Warga tersebut umumnya menumpuk sampah di pekarangannya atau membuangnya di lahan kosong sehingga lingkungan nampak kotor.

Beberapa upaya yang dilakukan warga adalah menangani sampah tersebut dengan cara membakarnya atau kadang-kadang mengumpulnya dan membuangnya di Tempat Pembuangan Sampah (TPS) milik Kelurahan Penfui di depan Pasar Penfui. Penanganan sampah di tingkat RT/RW tidak pernah dilakukan, sehingga masing-masing rumahtangga berupaya menanganinya secara individual. Salah satu cara untuk menangani sampah tersebut adalah dengan mengelolanya, baik secara individu dalam rumahtangga maupun dalam komunitas di tingkat RT/RW dan kelurahan, seperti dalam lingkungan mitra di RT 004/RW 002. Solusi lainnya yang dapat dilakukan untuk mengatasi masalah sampah adalah dengan memberdayakan ibu rumahtangga untuk mengelola sampah rumahtangga baik secara individu maupun kelompok. Pengelolaan sampah dapat dilakukan dengan mengintroduksi sistem R4 (reduce, reuse, recycle, dan replace) dilanjutkan dengan R5 (resell). Booth (2012) yang disitir Herliani, Humaedi, dan Adharani (2018) menegaskan bahwa recycle, misalnya, adalah salah satu strategi pengelolaan sampah padat terdiri dari kegiatan pemilahan, pengumpulan, pemrosesan, pendistribusian, dan pembuatan produk/material bekas pakai dan komponen utama.memisahkan sampah organik dan anorganik untuk memproduksi barang baru yang bermanfaat

Salah satu kegiatan dari pengelolaan sampah adalah dengan mengolahnya menjadi produk yang lebih bernilai. Sampah organik rumahtangga maupun dari area sekitar pemukiman berupa jerami rumput alam maupun gulma semak bunga putih (Chromolaena odorata) dapat diolah menjadi pupuk bokashi. Pupuk bokashi yang dihasilkan mitra dapat digunakan untuk menyuburkan tanaman rempah dan tanaman lainnya maupun untuk dijual. Harga jual bokashi di Kota Kupang yang relatif tinggi yakni Rp. 1.000,-- sampai Rp. 2.500,-/kg menyebabkan bokashi dapat dijadikan suatu produk yang memiliki peluang pasar sehingga dapat diproduksi oleh mitra untuk meningkatkan pendapatannya.

Kendalanya adalah: 1) pengetahuan dan keterampilan mitra masih terbatas untuk mengolah, menggunakan atau memasarkan pupuk bokashi dari sampah organik rumahtangga dan gulma serta rumput di sekitarnya sehingga menjaga kebersihan dan meningkatkan pendapatan; dan 2) mitra belum memanfaatkan waktu luangnya untuk menghasilkan produk yang inovatif dan kreatif berupa pupuk dari sampah organik di sekitarnya dan memanfaatkannya sebagai pupuk bagi tanaman rempah. 
Berdasarkan uraian di atas maka telah dilakukan kegiatan Pengabdian pada Masyarakat dalam skema Program Kemitraan Masyarakat (PKM) ini.

\section{Tujuan Kegiatan Pengabdian Pada Masyarakat}

Tujuan kegiatan Pengabdian pada Masyarakat dalam bentuk PKM ini adalah untuk: 1) meningkatkan keterampilan ibu rumahtangga mitra dalam mengolah sampah organik rumahtangga, serta jerami rumput alam dan gulma Chromolaena odorata menjadi bokashi untuk menjaga kebersihan lingkungan; 2) memanfaatkan bokashi bagi tanaman rempah atau menjualnya sehingga meningkatkan pendapatan, dan 3) meningkatkan produksi tanaman rempah untuk kebutuhan sehari-hari atau dijual.

\section{MASALAH}

Para ibu rumahtangga maupun warga lainnya di RT 004/RW 002 selalu mengalami kesulitan dalam mengelola sampah. Sampah biasanya ditumpuk di sudut pekarangan lalu dibakar atau sesekali dibuang di Tempat Pembuangan Sampah (TPS) Kelurahan Penfui di pasar Penfui. Kondisi ini menunjukkan bahwa kebutuhan pokok dari mitra adalah pelatihan dan pendampingan dalam hal pengelolaan sampah. Salah satu cara pengelolaan sampah, khususnya sampah organik adalah dengan mengolahnya menjadi bokashi. Sampah organik tersebut berasal dari sampah rumahtangga maupun dari jerami rumput alam, dan gulma Chromolaena odorata di sekitarnya. Bokashi yang dihasilkan dapat digunakan sendiri misalnya untuk memupuk tanaman rempah atau untuk dijual.

Rempah biasanya digunakan sebagai bumbu dapur maupun herbal. Kebutuhan keluarga akan rempah lokal seperti sereh, kunyit, dan lombok walaupun relatif sedikit namun selalu digunakan sebagai penyedap masakan sehari-hari. Jika rempah tersebut dapat diproduksi sendiri akan mengurangi pengeluaran keluarga dan menambah keasrian pekarangan. Adanya gerakan penanaman rempah bagi mitra melalui PKM ini bermanfaat untuk memenuhi kebutuhan bumbu dapurnya sehari-hari serta untuk menciptakan keasrian lingkungan setempat. Pemupukan tanaman rempah dengan pupuk organik berupa bokashi dapat pula meningkatkan produktivitas tanaman rempah serta menghijaukan pekarangan maupun lingkungan mitra. 


\section{METODE}

Metode yang digunakan untuk mencapai tujuan di atas mencakup kegiatan penyuluhan, praktek atau pelatihan tentang cara mengolah bokashi, cara membuat media tanam untuk tanaman rempah dengan memanfaatkan bokashi sebagai pupuk, dilanjutkan dengan kegiatan pendampingan, dan evaluasi. Cara pengolahan bokashi didasarkan pada suatu metode dari hasil kaji tindak Tim Fapet Undana di Kabupaten Rote - Ndao tahun 2004 dan 2007 serta Setiawan (2010).

Tahapan-tahapan metode tersebut pada prinsipnya untuk meningkatkan pengetahuan dan keterampilan mitra dalam mengolah, memanfaatkan bokashi bagi tanaman rempah, dan memasarkan bokashi. Tahapan evaluasi hasil dilakukan berdasarkan jumlah dan mutu bokashi yang dihasilkan dan dijual serta pemanfaatan bokashi bagi tanaman rempah.

Kegiatan penyuluhan dan pelatihan langsung dilakukan di rumah Ketua RT 004/RW 002 Kelurahan Penfui Kota Kupang pada tanggal 25 Mei 2019. Kegiatan pendampingan dilakukan sekali sebulan sejak Juni hingga September 2019 di pekarangan para peserta mitra.

Bokashi yang diolah di lokasi mitra terdiri atas tiga macam, yakni bokashi serasah (dedaunan kering), bokashi jerami rumput alam, dan bokashi gulma Chromolaena odorata. Hal ini sesuai dengan pendapat Aklis dan Masyurukan (2016) bahwa pengolahan sampah organik dapat pula dilakukan dengan menggunakan bahan baku berupa rerumputan dan batang pisang dengan bioaktivator EM4. Dalam kegiatan PKM ini, serasah diperoleh dari dedaunan kering dari pekarangan mitra terutama dedaunan tanaman buah-buahan seperti daun mangga, jambu air, sawo ungu, dan nangka. Bahan baku bokashi berupa jerami rumput alam dan gulma Chromolaena odorata diperoleh dari tepi jalan, lahan kosong, dan pekarangan warga.

Pada prinsipnya pengolahan ketiga jenis bokashi tersebut sama, namun ada beberapa hal yang perlu diperhatikan. Serasah, misalnya, perlu dibakar lalu disirami air untuk mendapatkan arangnya, sedangkan jerami rumput dan Chromolaena odorata harus dicacah dengan ukuran 3-5 cm untuk memudahkan pencampuran, fermentasi, dan proses penguraiannya menjadi pupuk bokashi. 
Pada kegiatan penyuluhan diberikan juga pembekalan tentang cara membuat media tanam untuk tanaman rempah dengan memanfaatkan pupuk bokashi serta cara penanamannya dengan menggunakan wadah plastik bekas berupa jerigen. Materi penyuluhan lainnya juga diberikan yakni tentang pemilihan jenis tanaman rempah yang membutuhkan air terbatas sehingga cocok untuk lahan kering.

\section{MATERI KEGIATAN}

Materi yang digunakan dalam PKM ini adalah bahan organik berupa serasah, sekam padi, dedak padi, kotoran sapi, jerami rumput alam, dan gulma Chromolaena odorata, EM4 pertanian, serta air dan gula. Peralatan pendukung adalah terpal, sekop, timbangan fer, karung, plastik, tali rafia, dan ember.

\section{Teknik Pengambilan Contoh}

Pengambilan contoh mitra dilakukan secara sengaja (purposive sampling) didasarkan pada pertimbangan bahwa responden adalah ibu rumahtangga warga RT 004/RW 002 yang bersedia menjadi mitra. Jumlah responden yang diambil adalah 8 orang dari 19 Kepala Keluarga (KK) atau sebanyak 42,11\%. Selain responden tersebut, peserta kegiatan juga mencakup para tetangga dari RT dan Kelurahan Liliba yang tertarik dengan kegiatan PKM pengolahan sampah ini.

\section{Teknik Pengumpulan Data}

Pengumpulan data dilakukan secara survei. Tahap pertama adalah survei lokasi dan lokasi terpilih adalah RT 004/RW 002 Kelurahan Penfui Kota Kupang. Penentuan lokasi tersebut didasarkan pada pertimbangan bahwa banyak sampah yang dibuang begitu saja di lahan-lahan kosong dalam lingkungan RT tersebut, serta banyak rumput alam dan gulma Chromolaena odorata yang tumbuh di sepanjang jalan dan lahan kosong serta pekarangan warga. Tahap ke dua adalah melakukan pengumpulan data jumlah Kepala Keluarga (KK) melalui Ketua RT 004/RW 002 Kelurahan Penfui dan diperoleh 19 KK. Berdasarkan jumlah KK tersebut ditentukan secara purposif 8 (delapan) ibu rumahtangga mewakili 19 KK yang bersedia menjadi mitra.

\section{Analisis Data}


Analisis data dilakukan secara deskriptif kualitatif.

\section{Lokasi, Waktu, dan Durasi Kegiatan}

Lokasi kegiatan PKM ini adalah di RT 004/RW 002 Kelurahan Penfui Kota Kupang. Waktu pelaksanaan kegiatan adalah 25 Mei 2019, disusul dengan kegiatan pendampingan selama empat bulan, mulai bulan Juni hingga Oktober 2019. Durasi kegiatan mencakup enam bulan yang dimulai bulan April hingga Oktober 2019, yakni sejak proposal disetujui, pelaksanaan kegiatan, pendampingan, monitoring dan evaluasi, hingga pelaporan akhir.

\section{HASIL DAN PEMBAHASAN}

\section{Kegiatan Penyuluhan}

Kegiatan penyuluhan dilakukan di rumah Bapak Ketua RT 004/RW 002 Kelurahan Penfui Kota Kupang (Gambar 1). Waktu pelaksanaan kegiatan penyuluhan dan pelatihan adalah 25 Mei 2019. Peserta kegiatan PKM adalah para ibu rumahtangga dari RT tersebut berjumlah delapan (8) orang mewakili 19 KK dari warga RT 004/RW 002 sebagai mitra atau mencapai $42,11 \%$. Walaupun jumlah peserta mitra yang hadir kurang dari 50\%, namun kegiatan tersebut dihadiri pula oleh 17 orang tetangga dari RT lain dan tetangga dari Kelurahan Liliba, tokoh masyarakat yang berminat dalam kegiatan pengolahan sampah, serta 10 mahasiswa KKN dan 6 (enam) dosen pemateri. Luaran yang dihasilkan yakni produk bokashi dan tanaman rempah.

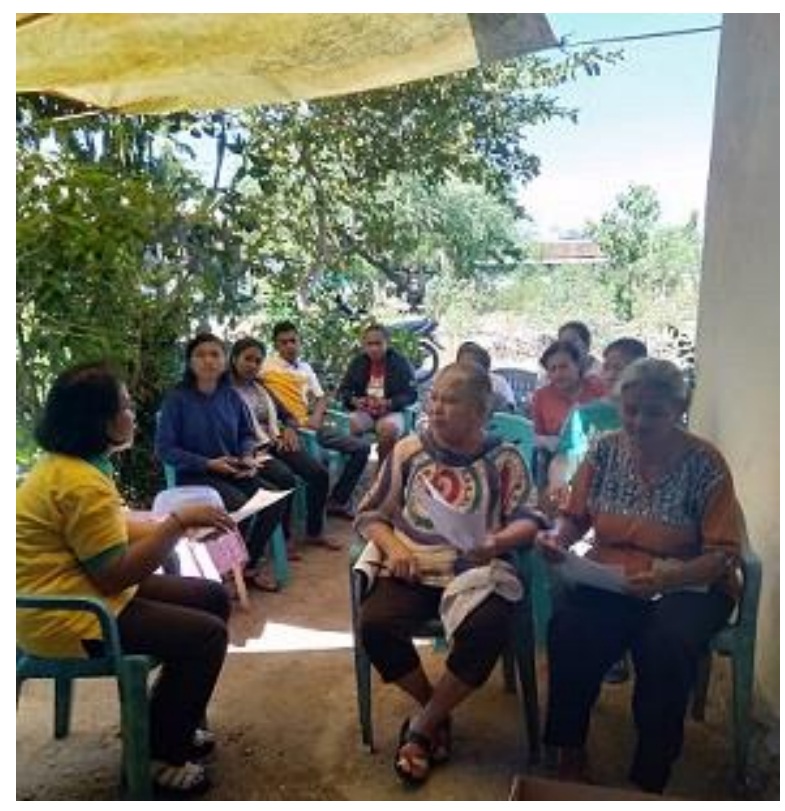

Gambar 1. Seorang Narasumber sedang Memberikan Penyuluhan kepada Mitra. 
Materi yang diberikan dalam kegiatan ini adalah tentang keuntungan dari pengelolaan sampah rumahtangga yakni dengan mengolahnya menjadi pupuk bokashi dan memanfaatkannya bagi tanaman rempah atau dijual, dibandingkan jika sampah tersebut hanya dibuang atau dibakar. Pengolahan sampah organik rumahtangga menjadi bokashi didasarkan pada pertimbangan bahwa bokashi mudah dibuat, biaya produksinya relatif murah, serta cepat dipanen yakni 4-7 hari.

Materi penyuluhan mencakup enam (6) topik, yakni : 1) Pemasaran Pupuk Bokashi dan Kerajinan dari Sampah Plastik (Ir. Arnoldus Keban); 2) Teknik Pengolahan Sampah Organik menjadi Bokashi (Ir. Maria R.D. Ratu, M.Sc.Agr); 3) Analisis Usaha Bokashi dan Tanaman Rempah (Ir. Johanes G. Sogen, MSc.); 4) Pemanfaatan Bokashi sebagai Pupuk Tanaman Rempah dan Tanaman Hias (Ir. G.A.Y. Lestari, MP.) ; 5) Pengolahan Sampah Anorganik menjadi Media Tanam (Dr. Ir. Markus M. Kleden, MP.), dan 6) Pengolahan Sampah Anorganik menjadi Bunga Plastik (Wienfrida Tulit Ina, ST., MT.). Seluruh narasumber berasal dari Universitas Nusa Cendana (Gambar 2 dan Gambar 3). Semua materi penyuluhan tersebut diberikan pula dalam bentuk hardcopy kepada segenap peserta kegiatan.

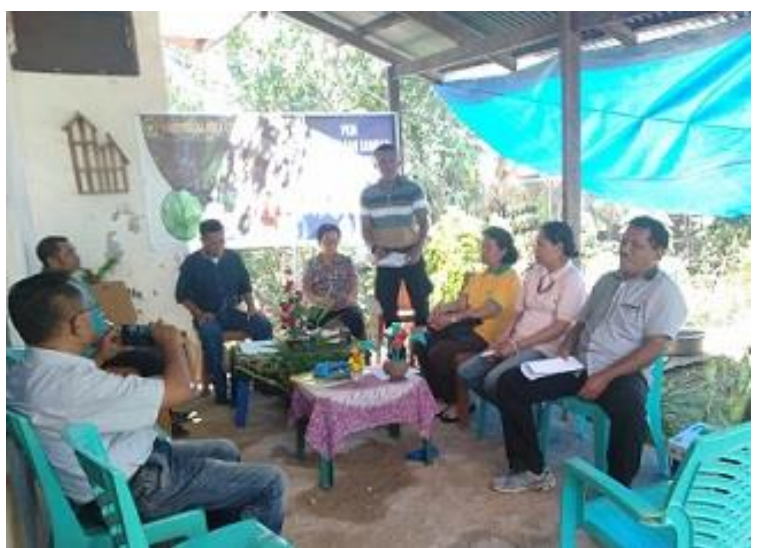

Gambar 2. Ketua RT 004/RW 002, Staf Kelurahan Penfui, dan Para Narasumber PKM.

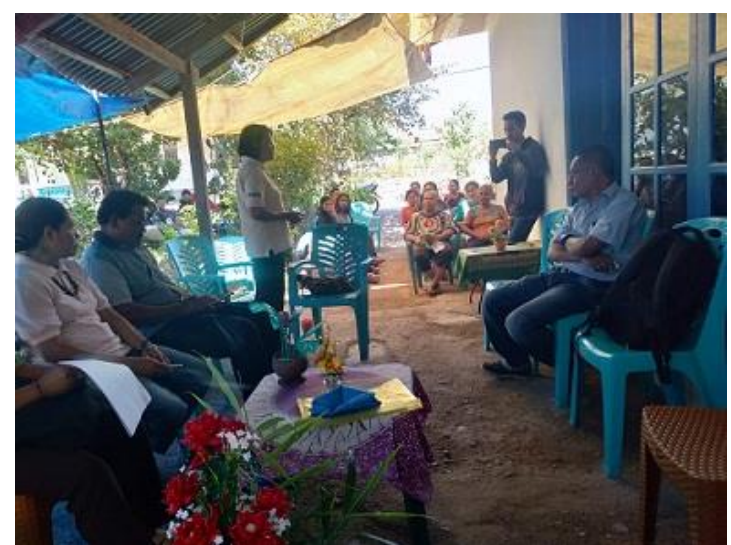

Gambar 3. Seorang Tim Pelaksana sedang Menyampaikan Tujuan Kegiatan PKM

Dalam pelatihan ini ada beberapa faktor yang perlu diperhatikan, yakni bahan baku bokashi, pencampuran, pemeraman, dan pemanenan bokashi. Narasumber/Pelatih juga menjelaskan keunggulan dan kelemahan dari masing-masing bahan utama bokashi seperti serasah, jerami rumput, dan gulma Chromolaena odorata (Gambar 4 dan Gambar 5). 


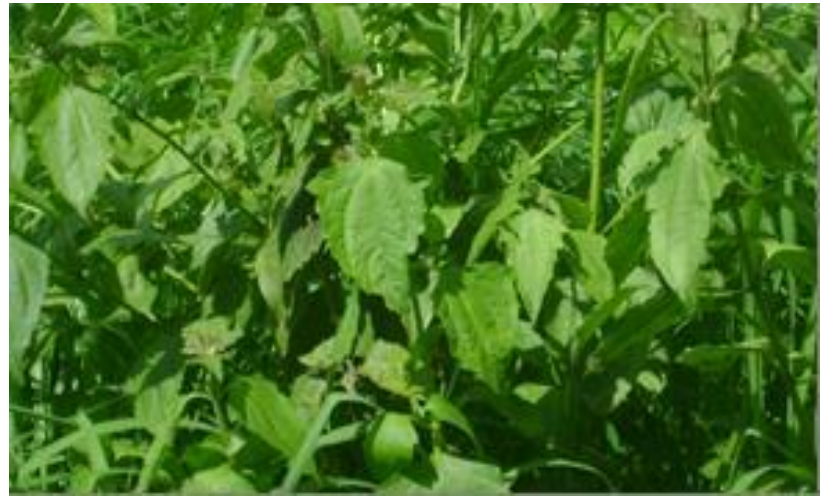

Gambar 4. Gulma Chromolaena odorata sebagai Contoh Bahan Baku Bokashi.

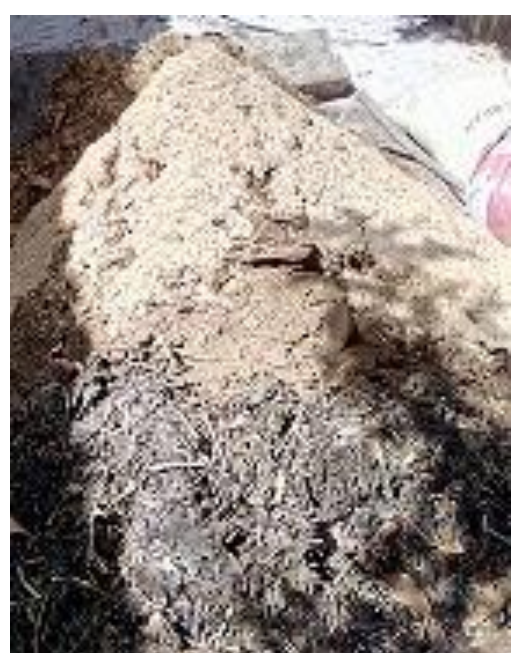

Gambar 5. Aneka Bahan Baku Bokashi.

Selanjutnya adalah pemanfaatan bokashi sebagai pupuk bagi tanaman rempah (Gambar 6). Narasumber atau pelatih pun menjelaskan rasio pupuk bokashi dengan tanah dan sekam yang digunakan sebagai media tanam untuk menanam tanaman rempah. Ratio antara pupuk bokashi : tanah : dan sekam/sekam bakar adalah $1: 1: 1$.

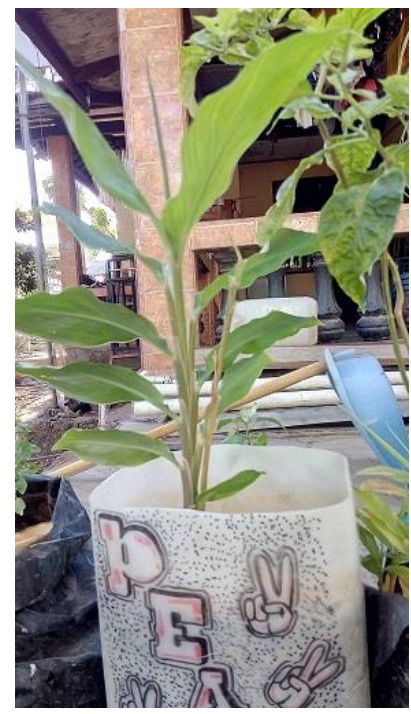

Gambar 6. Tanaman Bangle sebagai Tanaman Rempah yang Dipupuk dengan Bokashi dan Ditanam dalam Pot Plastik Bekas.

Ketika masa pemanenan pupuk bokashi tiba, maka mitra perlu menghitung jumlah produksi pupuk serta nilainya bila pupuk tersebut dijual. Dalam pelatihan awal dibuat $250 \mathrm{~kg}$ bokashi yang dijual dengan harga Rp. 2.500,-/kg sehingga total nilai bokashi yang diproduksi pada saat pelatihan adalah Rp. 625.000,-. Harga jual tersebut relatif lebih mahal dibandingkan harga jual bokashi di pasaran Kota Kupang yakni Rp. 1.000,-/kg, namun konsumen di wilayah setempat tetap mau membelinya karena kualitas bokashi cukup baik. Dalam pelatihan ini 
ditekankan pula pentingnya pengemasan untuk memudahkan distribusi dan pemasaran produk (Gambar 7). Hal ini sesuai dengan pendapat Kotler dan Armstrong (1994) yang menegaskan bahwa pengemasan merupakan alat penting dari pemasaran, karena memudahkan pengangkutan dan distribusinya serta mampu menarik atau menciptakan perhatian konsumen secara cepat.

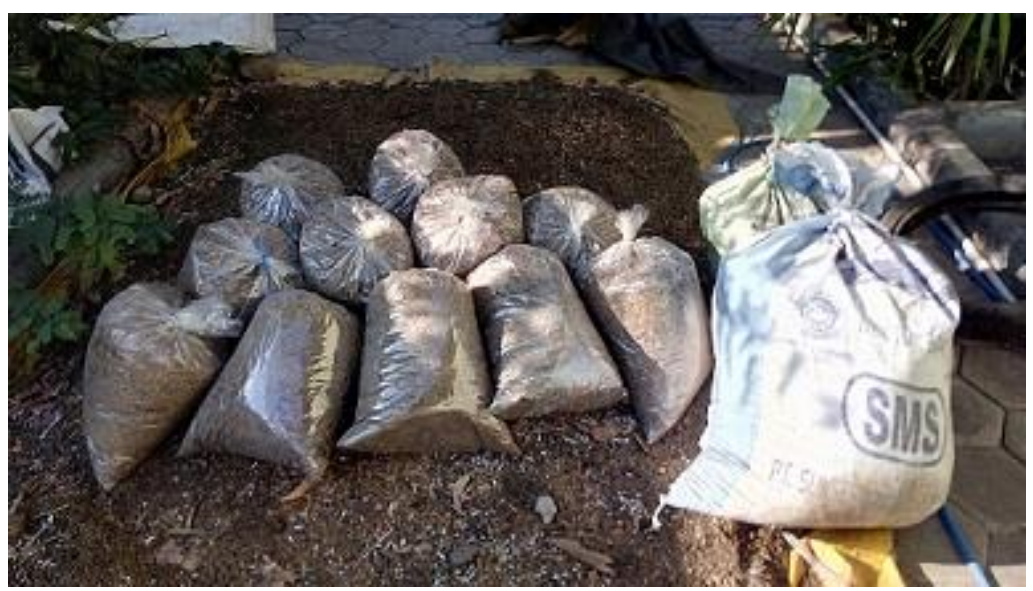

Gambar 7. Panenan Bokashi yang telah Dikemas dalam Kemasan Plastik Ukuran 5 kg.

\section{Kegiatan Pendampingan}

Kegiatan pendampingan dilakukan oleh salah satu anggota tim pelaksana. Jika ada permasalahan yang dihadapi mitra, maka mitra dapat menyampaikannya kepada pendamping. Masalah yang sering dihadapi mitra adalah mereka sulit mendapatkan kotoran sapi, sehingga solusinya adalah membuat bokashi campuran serasah dengan jerami dan gulma Chromolaena odorata. Hasil olahan bokashi serasah dan rumput dapat dilihat pada Gambar 8.

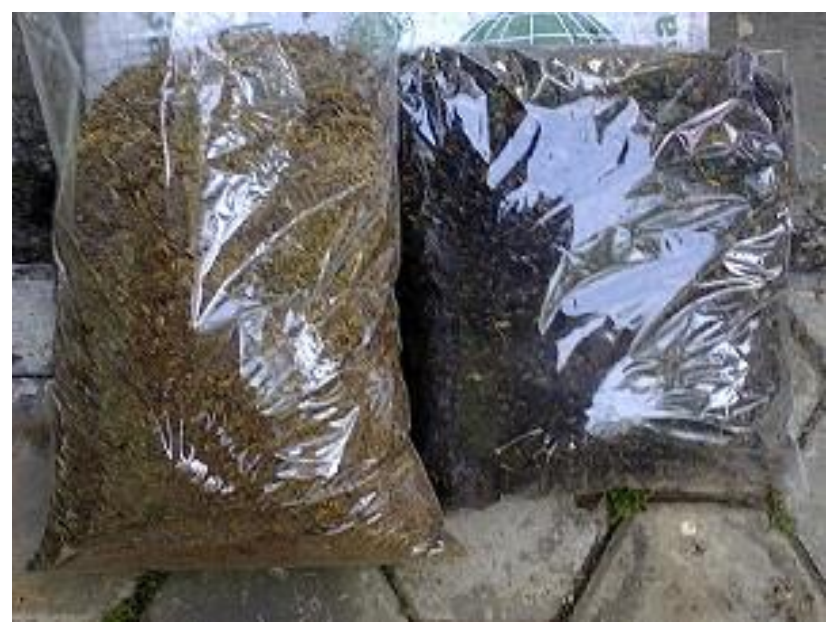

Gambar 8. Bokashi dari jerami Rumput (Warna Krem) dan Serasah Bakar (Warna Hitam) dalam Kemasan $5 \mathrm{~kg}$. 
Masalah ke dua yang sering didiskusikan adalah teknik pemasaran bokashi dan cara memanfaatkannya sebagai pupuk tanaman rempah, tanaman buah-buahan, maupun tanaman hias (Gambar 9).

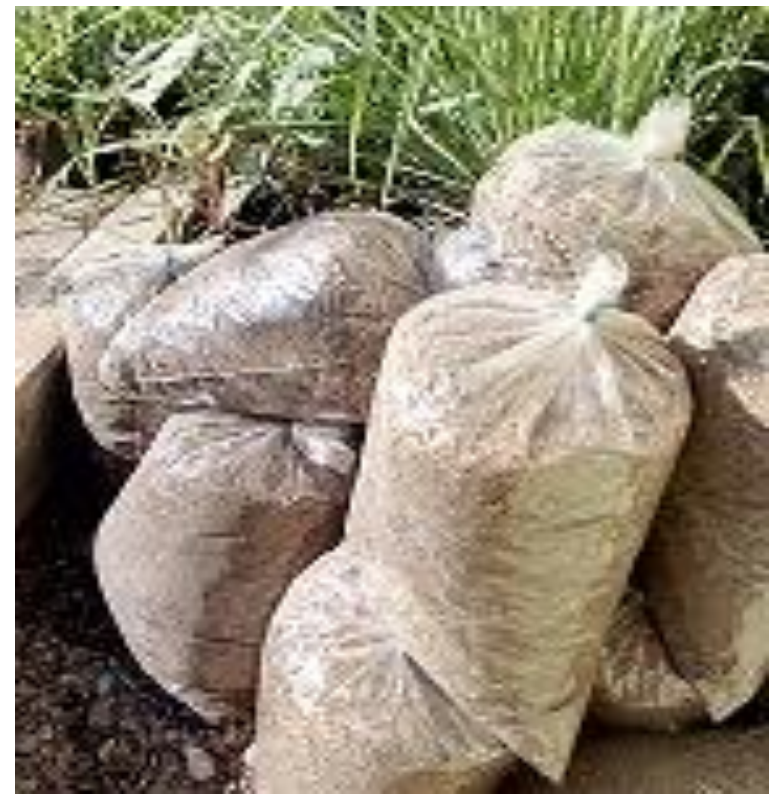

Gambar 9. Pupuk Bokashi dan Tanaman Sereh sebagai tanaman rempah hasil PKM yang siap dijual.

Selama pelatihan telah diberikan pula contoh atau praktek menanam tanaman rempah berupa kunyit, kencur, dan sereh dengan menggunakan pupuk bokashi yang telah disiapkan terlebih dahulu. Hal penting yang ditekankan dalam praktek tersebut adalah tentang pupuk, ratio tanah, serta sekam, yakni 1:1:1 untuk tanaman rempah kategori rimpang tersebut berbeda jika pupuk bokashi digunakan untuk menanam tanaman hias, tanaman buah-buahan, maupun tanaman sayuran. Untuk tanaman sayuran sawi dalam bedengan, misalnya, pupuk bokashi dapat diberikan sebanyak 3-4 genggam untuk ukuran bedeng $(1 \times 2) \mathrm{m}^{2}$.

\section{KESIMPULAN DAN SARAN}

Berdasarkan hasil dan pembahasan maka dapat ditarik kesimpulan sebagai berikut:

1. PKM ini dapat meningkatkan keterampilan ibu rumahtangga mitra dan peserta lainnya dalam mengolah sampah organik rumahtangga, serta jerami rumput alam dan gulma Chromolaena odorata menjadi bokashi untuk menjaga kebersihan pekarangan dan lingkungan setempat.

2. Mitra dapat memanfaatkan bokashi bagi tanaman rempah atau menjualnya sehingga meningkatkan pendapatan. 
3. Pupuk bokashi dapat digunakan untuk meningkatkan produksi tanaman rempah bagi kebutuhan sehari-hari atau dijual.

\section{UCAPAN TERIMA KASIH}

Ucapan terimakasih yang berlimpah disampaikan kepada Rektor Universitas Nusa Cendana dan Ketua LPPM Universitas Nusa Cendana yang telah memfasilitasi kegiatan PKM ini melalui dana DIPA Undana 2019. Terima kasih juga dihaturkan kepada Lurah Penfui, Ketua RT 004/RW002 Kelurahan Penfui Kota Kupang dan para peserta mitra.

\section{DAFTAR PUSTAKA}

Akhlis, N., dan Masyrukan, 2016. Penanganan Sampah Organik dengan Bank Sampah Komposter di Dusun Susukan Kelurahan Susukan Kecamatan Susukan Kabupaten Semarang Jawa Tengah. Jurnal Warta 19 (1): 72-82.

Herliani, Y. K., S. Humaidi, Y. Adharani, 2018. Pengetahuan, Keterampilan, dan Motivasi Warga Desa Jatiroke dalam Pengelolaan Sampah secara Mandiri. Jurnal Pengabdian kepada Masyarakat 2 (1): 23-36.

Kotler, Ph., and G. Armstrong, 1994. Principle of Marketing. Sixth Edition. Prentice Hall International Editions. Prentice Hall, Inc. A Paramount Communications Company Englewood Cliffs, NJ 071632.

Tim Fapet Undana di Kabupaten Rote-Ndao, 2004. Kaji Tindak Pengendalian dan Pemanfaatan Semak Bunga Putih (Chromolaena odorata) sebagai Basis Pengembangan Pertanian Organik Terpadu di Kabupaten Rote Ndao. Laporan Penelitian. Kerjasama Fapet Undana Kupang dengan Pemda Rote Ndao.

Tim Fapet Undana di Kabupaten Rote-Ndao, 2007. Pendidikan dan Latihan Pengendalian serta Pemanfaatan Semak Bunga Putih (Chromolaena odorata) sebagai Basis Pengembangan Pertanian Organik Terpadu di Kabupaten Rote Ndao. Laporan Pengabdian pada Masyarakat. Kerjasama Fapet Undana Kupang dengan Pemda Rote-Ndao. 